\title{
ORGANIZATIONAL GOALS: ANTECEDENTS, FORMATION PROCESSES, AND IMPLICATIONS FOR FIRM BEHAVIOR AND PERFORMANCE
}

\author{
Josip Kotlar \\ Lancaster University Management School \\ Lancaster, LA1 4YX, United Kingdom \\ j.kotlar@lancaster.ac.uk \\ Alfredo De Massis \\ Free University of Bozen-Bolzano \\ Bolzano, 39100, Italy \\ $\&$ \\ Lancaster University Management School \\ Lancaster, LA1 4YX, United Kingdom \\ a.demassis@lancaster.ac.uk \\ Mike Wright \\ Imperial College Business School \\ Exhibition Road, 46, London, SW7 \\ and \\ ETH, Zurich \\ mike.wright@imperial.ac.uk \\ Federico Frattini \\ Politecnico di Milano \\ 4/b Via Lambruschini, Milano, 20133 , Italy. \\ federico.frattini@polimi.it
}

Paper accepted for publication in the International Journal of Management Reviews

Please cite as:

Kotlar, J., De Massis, A., Wright, M., \& Frattini, F. (2018). Organizational goals: antecedents, formation processes and implications for firm behavior and performance. International Journal of Management Reviews, 20, S3-S18. 


\title{
ORGANIZATIONAL GOALS: ANTECEDENTS, FORMATION PROCESSES, AND IMPLICATIONS FOR FIRM BEHAVIOR AND PERFORMANCE
}

\begin{abstract}
The existence of definite organizational goals is a longstanding and central premise in organization and management research, yet a reexamination of this body of knowledge is timely and long overdue. Many important aspects of organizational goals have received very fragmented attention and there has been little prior attempt to synthesize and compare the effects of these different goals on firm behavior and performance. We present a review of existing theoretical and empirical evidence on organizational goals, and develop an analytical framework emphasizing the variety of organizational goals, their attributes, antecedents and outcomes, the role of context and feedback loops. Drawing on this framework we set out an agenda for further research aimed at advancing current understanding of organizational goals and implications for firm behavior and performance.
\end{abstract}

\section{Introduction}

The existence of definite organizational goals is a central premise in organization and management research. It is more than 50 years since Cyert and March's (1963) study on the behavioral theory of the firm and more than 30 years since Fama and Jensen's (1983a, 1983b) work on the effects of differences in goals arising from variety of ownership and control. Several decades since the publication of these seminal studies, organizational goals continue to play a central role in management research (e.g., Argote \& Greve, 2007; Fiegenbaum, Hart, \& Schendel, 1996; Greve, 2003; Shinkle, 2012) and practice (e.g., Collins, 2017; Kaplan \& Norton, 2007; Levinson, 2003). However, many important aspects of organizational goals, especially those related to their antecedents, the processes through which they are formed, and their organizational consequences, have received very fragmented attention, and are thus only loosely integrated in our understanding of organizational behavior and performance. This lack of understanding is given added emphasis by recent political and social trends from parties of both the left and right that call into question the purpose of the corporation and its role in addressing social and environmental challenges (Mayer, Wright, \& Phan, 2017; Phan, Siegel \& Wright, 2016; 
Mitchell et al., 2016; Porter \& Kramer, 2014). Thus, a reexamination of the concept of organizational goals, as well as their antecedents and consequences, is timely and long overdue.

Given the importance of goal setting for predicting organizational behaviors and outcomes, it is essential to develop a more detailed and comprehensive understanding of the factors affecting firms' decisions to pursue a specific set of goals. In this article, we present a review of existing theoretical and empirical evidence on organizational goals, and develop an analytical framework emphasizing the variety of goals pursued by business organizations, their antecedents, formation processes and outcomes, the role of context and feedback loops. We then provide an overview of the articles published in this special issue and conclude by proposing an agenda to inform future studies in this area.

\section{The Multiple Facets of Organizational Goals}

Organizational goals can be broadly defined as desired organizational outcomes that can be used to guide action and appraise organizational performance (e.g., Mohr, 1973) but distinct from measurable targets (March \& Simon, 1958). There has been much debate about what actually constitutes an organizational goal, and different theoretical traditions offer different conceptualizations. In classic economic theory, firms were traditionally seen as monolithic actors that, under the assumption of perfect rationality, pursue a unitary goal of profit maximization. However, this perspective was critically extended over the years. For example, scholars have argued that "official" goals stated in vision and mission statements do not always accurately reflect what actually drives organizational behaviour (e.g., Perrow, 1961). Most notably, in the seminal book "A Behavioral Theory of the Firm”, Cyert and March (1963) noted that people have goals, but collectivities of people do not. Subsequently, researchers have put substantial effort at understanding the individual goals of those individuals who are most able to influence what the organization actually does, including 
emphasis on major decision makers, the executive core, or the dominant coalition (Connolly, Conlon, \& Deutsch, 1980). Cyert and March (1963) argued that organizational goals are not unitary and given, and emphasized that the firm is a coalition of shareholders, managers, employees, and other parties, each with their own goals. Thus, organizational goals are the result of continued bargaining and stabilization processes among relevant parties within the firm, leading to multiple dimensions along which organizational goals are set, including production, inventory, sales, market share, and profitability. Moreover, behavioral theory suggests that organizational goals influence firm behavior through processes of satisficing, search, adaptive learning, and sequential attention (Cyert \& March, 1963; March \& Simon, 1958). These basic insights had a tremendous impact on subsequent theory and research (Argote \& Greve, 2007), resulting in a variety of related perspectives each putting emphasis on different dimensions and characteristics of organizational goals.

Fiegenbaum et al. (1996) integrated major theoretical perspectives to form a threedimensional matrix of organizational goals. Specifically, motivation theory (Latham \& Yukl, 1975), prospect theory (Kahneman \& Tversky, 1979) and the resource- based view of the firm (Barney, 1991) provide insights about the content of organizational goals, such as strategic inputs used to evaluate employees' performance, and strategic outputs used to evaluate the performance of managers. Industrial economics (Porter, 1980), resource dependence (Pfeffer \& Salancik, 1978), and institutional theory (DiMaggio \& Powell, 1983) perspectives, in turn, elucidate the terms of reference firms use to evaluate organizational goals in relation to the external environment, including competitors, customers, and other stakeholders. Finally, Fiegenbaum et al. (1996) underscore the importance of time as a further dimension of organizational goals, suggesting that they can be defined either in relation to the past accomplishments, as per corporate identity (Dutton \& Dukerich, 1991) and 
organizational learning (Levitt \& March, 1988) perspectives, or in relation to future ambitions as per the strategic intent perspective (Hamel, Doz, \& Prahalad, 1989).

In addition to underlying the multi-dimensional nature of organizational goals, prior research also emphasizes that organizational goals are directly linked to goals at other levels of analysis, including individual, group and institutional levels. Finally, directly emanating from the behavioral theory of the firm is the notion that organizational goals are dynamic and change over time in response to changes in internal or external factors (Ansoff, 1979).

Taken together, these theoretical perspectives and related research streams emphasize the primacy of organizational goals in directing firm behavior and performance, as well as the complexity arising from their multi-dimensional and dynamic nature. Because organizational goals are inherently complex, it is not surprising that the measurement of organizational goals remains an important and still largely unresolved issue for both management research and practice (Cameron, 2010; Richard et al., 2009; Venkatraman \& Ramanujam, 1986). In this regard, Venkatraman and Ramanujam (1986) note that organizations have both financial and operational goals and highlight how measurement of organizational goals is constrained by availability of data, especially when it comes to operational goals, for which primary sources of data are needed, . In practice, the "balanced scorecard" approach (Kaplan \& Norton, 2007) has long been used to address the complexity of dealing with multiple goals. Although the balanced scorecard provides a simplified tool to manage multiple organizational goals, this approach offers only a partial answer to managers' need to understand how complex sets of goals interact to influence multiple outcomes.

In sum, existing research on organizational goals is large and provides a wealth of insights for both management research and practice. In reviewing and synthesizing this body of research we aim for a more unified perspective that provides a comprehensive understanding of organizational goals and their role in business organizations, identifies 
critical gaps in current research, and points to future research directions that can contribute to move this field forward. Such a comprehensive literature review is important as organizational goals have great practical and theoretical importance and also because assumptions about organizational goals represent, either implicitly or explicitly, the core assumptions on which organization and management research is built.

\section{Opening the "Black Box" of Organizational Goals}

We summarize existing research on organizational goals in Figure 1, which provides a comprehensive view of organizational goals in terms of their varying content and attributes, antecedents, and outcomes. Moreover, the model emphasizes the role of context as well as feedback loops that underlie the dynamic nature of organizational goals. Our analysis underscores the multi-level nature of organizational goals in relation to both their antecedents and outcomes.

\section{Figure 1 about here}

\section{Variety of Organizational Goals: Goal Content and Attributes}

Among the variables representing the goals an organization may pursue, researchers have mostly focused on profitability (Greve, 2003), which has direct consequences for managers' careers and job market value. But organizations often pursue other goals including productivity, sales, market share, and status (Baum et al., 2005). Indeed, research acknowledges the existence of a broad and very heterogeneous array of organizational goals that go beyond profit (e.g., Fiegenbaum et al. 1996). Cyert and March (1963) emphasized different dimensions of the organizational goal construct that reflect the focus of different coalitions within the firm. This early conceptualization was subsequently significantly expanded, specifically with the rise of research on corporate social responsibility, on the one hand, and institutional theory on the other, which respectively inform two main dimensions of organizational goals from prior literature. 
First, organizational goals can be either financial or non-financial. Financial goals, particularly profit maximization, was long emphasized in early management literature, perhaps reflecting the nature of business during the industrial revolution in the nineteenth century, when firms operated in economic scarcity and were almost unaffected by any interference from the government (Chrisman \& Carroll, 1984). The emphasis on profits as a unitary organizational goal was also legitimized by classical economic theory based on Adam Smith's “invisible hand", which would ensure that each individual actor's behaviors, even if driven by self-interest, would lead to the promotion of the public good (Hay \& Gray, 1974). During the 1980s, the emphasis on profits became encapsulated in the goal of maximizing shareholder value (Rappaport, 1986). For example, central to the economic "theory of the firm" is the notion that managers' primary job is to maximize profit in order to create value for shareholders, thereby seeing any behavior that deviates from profit maximization as inherently inefficient, if not immoral (e.g., Fama, 1980; Jensen \& Meckling, 1976). However, around this time the advent of the notion of corporate social responsibility led management scholars to begin to reevaluate the role of business in society and to recognize the broader contribution of business to overall societal welfare (Donaldson \& Preston, 1995; Freeman, 1984). Governments gradually introduced a large number of socially motivated laws and regulations through which they increased their influence on business. Thus, the legitimacy of business organizations as an institution came into question, and firms started to consider a wider set of non-financial goals (Ansoff, 1979) reflecting their relation to broad societal issues. The corporate social responsibility literature identifies a large number of nonfinancial, or social goals, including fulfilling community needs, building positive labor relationships, improving public image, and good citizenship (Keim, 1978). These goals coexist, and sometimes conflict, with the organization's financial goals. 
A second important content dimension of organizational goals relates to their sources, which can be either internal or external. Internal organizational goals reflect the interests of the coalitions within the firm, for example profit maximization is viewed as the ultimate financial interest of shareholders, whereas growth has typically been seen as a main focus of top management especially if they are not owners, productivity relates to the interests of operations and productivity managers, and quality reflects the interest of product management (cf. Cyert \& March, 1963). Moreover, the literature on the role of founders and founding families in business also emphasizes the importance of internal non-financial goals, which reflect the interests and concerns of these parties, such as the ability to exercise family authority, act altruistically toward family members, fulfill desires for belonging, affect and intimacy, and the perpetuation of the family values and dynasty (Chrisman et al., 2012; Gómez-Mejía et al., 2007; Kotlar \& De Massis, 2013). Research also acknowledges that firm's coalitions and different individuals may have, respectively, manifold group and individual goals that concur with the emergence of goal diversity (e.g., Cyert \& March, 1963). Moreover, a single individual may have multiple and conflicting goals at the same point in time, which may lead to self-control agency problems and influence firm behavior and performance (De Massis et al., 2016). Hence, goals can be heterogeneous across different firm's coalitions and different individuals in the same organization as well as for a single individual.

On the other hand, firms have multiple external stakeholders with heterogeneous goals, including institutions and regulatory bodies, the community, customers and the media (e.g., Freeman, 1984). External or institutional sources of organizational goals are particularly emphasized by institutional theorists (e.g., DiMaggio and Powell, 1983). Examples of external goals include status, rankings, and certifications, among many others. Interestingly, profit maximization is both an internal and external goal as, on the one hand, it responds to 
the firm's internal coalitions focus on obtaining side payments (Cyert \& March, 1963), while on the other hand it reflects the interests of the firm's shareholders who aim at increasing their wealth (Fama, 1980).

Besides the two main dimensions of organizational goals discussed above, prior research has identified a number of attributes that characterize organizational goals. Perhaps the most widely examined attribute of organizational goals is goal difficulty, which is a central element of goal setting theory and is defined as the probability that a goal can be achieved given current situational characteristics and resources (Locke \& Latham, 1990). Moreover, goals differ in terms of novelty, or the degree to which the paths for achieving a given goal are known given current capabilities (Sitkin et al., 2011). When goals are both extremely difficult and novel, they are defined as stretch goals (Gary et al., 2017; Kerr \& Landauer, 2004). Another important attribute of organizational goals is goal specificity (Locke \& Latham, 2002), also known as explicitness (Hollenbeck, Williams, \& Klein, 1989), which relates to the completeness of knowledge about what organizational outcomes would fulfill a desired goal (Hirst, 1987). Finally, research differentiates goals in terms of their duration, which defines the time horizons used to evaluate a goal (Loewenstein \& Thaler, 1989).

The content dimensions of organizational goals and their attributes discussed above collectively define the variety of organizational goals, representing the central element of the model presented in Figure 1.

\section{Antecedents of Organizational Goals}

Questions of what factors influence organizational goals and what are the mechanisms through which these factors operate have been addressed in a large body of research encompassing diverse theoretical perspectives and levels of analysis. Researchers have increasingly highlighted the need to understand the processes and mechanisms through which 
organizations can pursue a definite set of goals despite the different interests of their individual members. But, notably, Argote and Greve (2007) observed that despite the emphasis posed in Cyert and March's (1963) behavioral theory on conflicts of interest and internal bargaining among organizational members and coalitions thereof, the theoretical and empirical work exploring how organizational goals are formed is not nearly as refined as work done at the aggregate level.

Scholars in the behavioral theory tradition have suggested that organizational goals reflect the power of individual organizational members, organization units (Pearce \& DeNisi, 1983), or social groups (e.g., families; Kotlar \& De Massis, 2013). The mechanisms through which individual goals influence organizational goals have been substantiated by research in social psychology and political science, which has shown that individuals form coalitions to pursue their goals (Pearce \& DeNisi, 1983), as well as the processes and mechanisms that characterize group decision making (Hinsz, Tindale, \& Vollrath, 1997).

At the organizational level, several factors influence organizational goals such as firm age and size (Short \& Palmer, 2003) and firm resources (Audia \& Greve, 2006).

Organizations that differ in terms of industrial sector, size, ownership type, governance, or market position, among other characteristics, pursue diverse organizational goals. For example, service industry firms are likely to place profitability before size goals, whereas manufacturing firms may follow the opposite approach (Greve, 2008).

The upper echelon literature (e.g., Miller, Burke, \& Glick, 1998) has focused on the role of the CEO, the board of directors (BoD), and the top management team (TMT). Concerning the CEO, there is significant evidence that CEO goals depend critically on the proportion of firm shares they own (e.g., Martin, Gomez-Mejia, \& Wiseman, 2013). When considering the BoD and the TMT, scholars have particularly emphasized their demographic, structural and cognitive diversity (Glick, Miller, \& Huber, 1993), the level of consensus 
(Dess, 1987) or cohesion (Pitcher \& Smith, 2001), the goal congruence between parties such as between the CEO and the TMT (Colbert et al., 2008) or between family and non-family coalitions (Kotlar \& De Massis, 2013; Patel \& Cooper, 2014). The theory of stakeholder salience provides valuable insights about the mechanisms through which the goals of organizational coalitions influence organizational goals, particularly emphasizing factors such as power, urgency and legitimacy (Agle, Mitchell, \& Sonnenfeld, 1999).

Finally, prior research has identified antecedents of organizational goals at the institutional level, including the firm's industry and general economic conditions (Gooding, Goel, \& Wiseman, 1996). Relatedly, researchers in the institutional theory literature have emphasized how practices and structures that represent legitimate ways of operating in an industry influence organizational goals through mechanisms of adoption (DiMaggio \& Powell, 1983), in turn driven by the perception that a given practice and structure relates positively to firm performance (Barreto \& Baden-Fuller, 2006; Davis \& Greve, 1997). Outcomes of Organizational Goals

Prior research has emphasized the consequences of organizational goals at different levels of analysis. At the individual level, goal setting and human motivation theories link organizational goals to organizational members' motivation and commitment (Gollwitzer, 1996), as well as to a variety of individual performance indicators such as task performance (Mitchell \& Silver, 1990), organizational citizenship behavior (Podsakoff et al., 2000) or creativity (Shalley, 1991). Common in this research is the notion that a key mechanism through which organizational goals influence individual outcomes relates to the incentives and rewards provided to organizational members (Locke \& Latham, 2002).

Research on the outcomes of organizational goals at the group level has been based on similar theoretical positions and produced similar results. For example, prior studies have linked goal difficulty and specificity to collective motivation and commitment, group 
behavior (Lant, 1992) as well as group performance (O'Leary-Kelly, Martocchio, \& Frink, 1994). The outcomes of organizational goals at the organizational level have been a major subject in strategic management research, where scholars have examined the impact of organizational goals on firms' strategic behavior, including strategic risk taking (Bromiley, 1991), search (Chen \& Miller, 2007), organizational learning (Ben-Oz \& Greve, 2012) and, ultimately, firm performance. Behavioral theorists agree that organizations embrace strategic and operational change by introducing new products, entering new markets, engaging in M\&As, and increasing R\&D investments when they observe declining performance relative to their selected goals (Audia \& Greve, 2006; Chrisman \& Patel, 2012).

\section{Context}

Another recurrent topic in existing research on organizational goals is the role of context. Several scholars have emphasized the importance of external factors such as environments and institutions for organizational goals, including environmental instability (Gooding et al., 1996) and expectations from relevant institutions (Mezias, Chen, \& Murphy, 2002). However, we know relatively little about the influence of multiple contexts on the antecedents, variety and outcomes of organizational goals. In an attempt to integrate the role of context in our model, we focus on four broad categories of contexts.

First, the micro context refers primarily to individual choice and the local environment where decisions are made (Dopfer, Foster, \& Potts, 2004), and includes, among other factors, cognition, attention, and logics of individual organizational members (e.g., Locke, 2000). These contexts are likely to shape individual goals and influence the way organizational goals are both formed and implemented in organizations. Second, the meso context refers to the organization-level factors inside the firm, such as ownership and governance, generation of firm leadership, and resources, which are likely to influence the selection of organizational goals and create organizational-level boundaries for the 
implementation of organizational goals into action. The macro context includes the sector in which the firm operates, the cultural institutions in which the firm is embedded, the existing legal frameworks in a given society or state, and the technologies available to measure and predict the accomplishment of organizational goals. Finally, the chrono context refers to the factors that lead to evolutionary or punctuated changes in the institutional or organizational contexts affecting the organizational goals of firms. For instance, disruptive events along the life of an organization or the sector in which it operates, such as business exits, successions, waves of mergers and acquisitions, shifts in technological paradigms, may determine changes in the organizational goals (Decker \& Mellewigt, 2007; Kotlar \& De Massis, 2013). The behaviors of the stakeholders in family firms are influenced by the contexts in Feedback loops

Finally, a significant body of research points to the important role of feedback loops that originate from the outcomes of organizational goals and dynamically influence their antecedents and content (Shinkle, 2012). This research shows that firms continuously evaluate their performance against past performance or the performance of other firms (Iyer \& Miller, 2008; Mishina et al., 2010). Moreover, the behavioral agency model combines insights from prospect theory and agency theory to explain how discrepancies between aspiration and performance influence decision making through mechanisms of problem framing and loss aversion (Harris, Johnson, \& Souder, 2013).

The evaluation of performance relative to goal aspirations is further complicated by the existence of multiple goals that are not always independent from one another. Multiple organizational goals may have additive effects, jointly influencing a single outcome, as well as interactive effects, such that the accomplishment of one goal may lower or increase the saliency of another goal, following hierarchical rules (Greve, 2008). When organizational decision makers respond to performance feedback regarding different goals, such responses may follow a sequential attention (Ethiraj \& Levinthal, 2009; Greve, 2008) or a simultaneous 
attention logic (Labianca, Fairbank, Andrevski, \& Parzen, 2009; Shinkle, 2012). The former envisages that firms shift their attention as particular goals become more or less salient (March \& Shapira, 1992). Goals are weakly correlated and/or conflicting, and goal conflict is resolved with temporal differentiation, or sequential attention, where the accomplishment of one goal requires giving up others (Ethiraj and Levinthal, 2009). Under such circumstances, decision makers face "mixed gambles" and their decisions depend primarily on their consideration of goals in relation to current and prospective wealth (Martin, Gomez-Mejia, \& Wiseman, 2013), defined either in financial or non-financial terms (Kotlar et al., 2017). Nevertheless, organizational decision makers often pay simultaneous attention to multiple goals that are not necessarily uncorrelated or conflicting (Gaba \& Joseph, 2013; Greve, 2008; Labianca, Fairbank, Andrevski, \& Parzen, 2009). As goals are often hierarchically-related to each other such that intermediate goals may be instrumental to accomplishing the higherlevel goal of profit maximization (Ethiraj and Levinthal, 2009), performance feedback on multiple goals can occur simultaneously, calling decision makers to jointly formulate organizational responses (March \& Simon, 1958). In this circumstance, distribution of attention in response to performance feedback regarding hierarchically-related goals can be regulated by different rules (Ocasio, 1997) such as, for instance, priority-based or causalitybased attention rules.

\section{Papers in the Special Issue}

In this section, we situate the papers in the special issue within the over-arching framework of Figure 1. As summarized in Table 1, each literature review focuses on a different topic in relation to organizational goals, draws from different theoretical perspectives, and develops new arguments in response to existing research gaps. We discuss the insights offered by these articles in relation to our theoretical model about the antecedents, variety and outcomes of organizational goals. 
Greve and Teh (2017) examine and integrate the complementary insights provided by research using the behavioral theory of the firm and institutional theory to advance a behavioral theory of organizational responses to external goals. Specifically, they provide a comprehensive review of these two theoretical traditions, emphasizing their strengths and uncovering their respective limitations, and showing how the insights from each perspective can inform the other to provide a more complete understanding of both internal and external sources of organizational goals. The review identifies three main mechanisms through which external goals enter the organization internally. First, firms adopt external goals by creating a supportive dominant coalition that is responsive to institutional pressures. Interestingly, the authors note that the political support for pursuing external goals is stronger when external goals can be linked to other internal goals such as profitability, and can be influenced positively or negatively by external actors. Second, firms are more likely to adopt external goals when members of the dominant coalition see these goals as side payments to important stakeholders outside the firm. Third, external goals can become institutionalized, especially when firms deal with environmental uncertainty and the adoption of an external goal legitimizes the firm in its environment. Taken together, this paper points to the complementary gaps in the behavioral theory of the firm and institutional theory, making way for new studies at the intersection between these two theoretical perspectives.

Foss and Linder (2017) criticize the tendency of management scholars to ascribe goals to supra-individual entities such as organizational groups or firms, and to treat these entities as a unitary actor, and thus propose a "microfoundation" perspective aimed at decomposing the collective concept of organizational goals in terms of their lower-level constituent components. Thus, they examine organizational goals as a multilevel concept, and review antecedents and consequences of organizational goals across micro and macro levels of analysis. This review leads the authors to develop a microfoundational framework that 
explains how organizational goals form and how subsequently they affect organizational outcomes, providing valuable insights for future research that examines the cross-level processes underlying the antecedents and outcomes of organizational goals. In doing so, the authors also identify major theoretical perspectives that inform the micro-level factors (namely, social cognitive theory, theory of mind, elaboration likelihood model, social projection theory, mediating hierarchs and goal-framing theory) and macro-level factors (prospect theory, cognitive biases, individual-level goal setting theory, agency theory, and self-determination theory).

William, Pieper, Kellermanns, \& Astrachan (2017) provide a systematic review of the growing literature on family business goals, thus contributing new insights about the role of the meso context on organizational goals. Specifically, the authors note that family ownership and management are a common trait of most firms worldwide, and emphasize the role of family-centered goals as a building block of what constitutes a family business as well as a main driver of differences in behavior and performance between family and non-family firms. By reviewing the literature, they identify antecedents, characteristics, related outcomes, moderators and feedback loops that are unique to the family business context. In terms of antecedents, the authors underscore family presence, role of individual family members, founder influence and leadership, family history and culture, socioemotional wealth, organizational identity, succession intentions, and national culture and ethnicity. The review also informs our understanding of the characteristics of family firm goals in terms of the number and heterogeneity of such goals. The outcomes of family-centered goals include family member relationships, socioemotional wealth, governance, management, and strategy. Then, the review identifies several moderators of the relationship between goal antecedents, goal characteristics, and goal outcomes, including founder centrality, succession, and family involvement in management. Finally, the article clarifies the key elements that characterize 
feedback loops in relation to organizational goals, such as communication and interaction, conflict, community reputation, and the balanced scorecard. Taken together, this review article provides a holistic look at family business goal literature that has the potential to inspire new research directions and advance the understanding of goals in the wider management literature.

Gagné (2017) focuses on the consequences of organizational goals for the behavior of organizational members, addressing specifically the question of what mechanisms enable firms to transform organizational goals into individual goals and behaviors. The article draws on the theory of action phases to explain how organizations and employees commit to organizational goals and successfully pursue them. Moreover, it integrates insights from selfdetermination theory to explain how organizational members develop the motivation and commitment to pursue organizational goals. The theoretical model developed from these perspectives emphasizes specific phases through which organizational goals influence organizational members' behaviors, namely mission and strategic goal development, organizational level implementation, intentions in the form of strategic plans and dynamic capabilities, individual goal internalization, and implementation plans at the individual level. These goal phases are, in turn, influenced by the attraction, selection, socialization and management of organizational members. In sum, this model helps organize existing research on the individual-level outcomes of organizational goals, and guides future research in the area of behavioral strategy by integrating motivational considerations into strategic management models.

\section{Table 1 about here}

\section{Future Research Directions}

An agenda for future research based on the elements in the framework of organizational goals developed in Figure 1 is summarized in Table 2. 


\section{Table 2 about here}

While multiple goals are recognized, there is a need for further research into their nature and drivers across all levels. Much research has taken goals as given, yet we need to know more about where goals come from. Research is needed to explore the relationship between the nature of goals and outcomes in order to assess whether organizations are performing well or not. Such research is also important in assessing performance outcome differences between different types of firms. Important research questions arise concerning whether goals are driven endogenously or exogenously or through some combination of both. The variety of exogenous contextual factors are acknowledged (Zahra \& Wright, 2011), yet we have little systematic evidence on the differential impact of each of these contextual factors on organizational goals. For example, there may be conflicts between the goals of shareholders and managers and new mechanisms that change ownership and control may determine changes in these goals (e.g. executive stock options, private equity buyouts). There may also be conflicts between the goals of multiple principals and agents. Control by customer-owners in mutual firms diverts organizational goals from profits and growth toward creating customer welfare. Again, in firms characterized by a major overlap between ownership and control (e.g., family firms) managers lose incentive to pursue growth and profitability goals, and prioritize non-economic goals (Gómez-Mejía et al. 2007). A number of research questions also emerge in relation to the outcomes of organizational goals. Most importantly, addressing the conceptual gap between organizational goals and firm performance needs more attention in future research. If we define performance as achievement of goals, most of the performances reported in empirical studies must be classified only as outcomes because these studies did not specify the goals to be achieved; did not clarify the contexts within which the goals are to be achieved; and/or did not assess performance in terms of the extent to which the outcomes have achieved the goals. Further 
research questions relate to the impact of organizational goals on outcomes at the individual, group, and institutional levels. Moreover, it will be important for future studies to consider links between organizational goals and outcomes across both internal/external and financial/non-financial goals dimensions. Finally, a major area for further research concerns how organizational goals adapt to feedback loops regarding organizational outcomes and contextual changes. In particular how, at various levels, changes to goals are or are not implemented. Moreover, prior research has largely focused on feedback regarding a single performance goal, namely firm profitability (Shinkle, 2012), thereby replacing March and Simon's (1958) seminal notion that multiple goals coexist in organizations (Gaba \& Joseph, 2013; Gavetti et al., 2012). Thus, we are left with a gap in understanding of conditions leading decision makers to embrace different rules to guide attention and responses to performance feedback regarding multiple hierarchically-related goals.

Taken together, our theoretical framework and the articles published in this special issue have important implications for practice as well as for future research. In particular, an important issue concerns the need for organizations to define performance in relation to the goals they are aiming to achieve. Similarly, analysts need to assess performance in terms of the extent to which the outcomes have achieved the organization's goals. Also, our proposed framework can constitute a background policy document for policy makers. The goals of business organizations are being paid increasing attention in the public domain, and our study facilitates understanding of the various types of goals and their attributes, and can support policy makers in their decisions on how to build a system of supporting initiatives for organizational goals in line with the social and environmental challenges they aim to address.

\section{Conclusion}

This paper starts from acknowledging the need for a reexamination of the vast theoretical and empirical research on organizational goals. Through a review of the literature, 
we develop an analytical framework that is helpful to synthetize theoretical and empirical research on organizational goals, by focusing on the variety in type of goals an organization may pursue, the goal attributes, antecedents and outcomes, the contextual influences on goal setting, and the feedback loops through which the achievement of goals influences their formation and organizational decision making. This framework is used to position the contributions of the papers published in the special issue against existing theoretical and empirical research on organizational goals, and propose an agenda for future research by delineating a number of important research questions that need to be addressed if theories around the complex issues of organizational goals, their antecedents, formation processes, and implications for firm behavior and performance are to move forward. As the purposes of business organizations come under unprecedented scrutiny in political, social and economic debate, we believe that this research agenda has increasing relevance and impact.

\section{References}

Agle, B. R., Mitchell, R. K., \& Sonnenfeld, J. A. (1999). Who matters to CEOs? An investigation of stakeholder attributes and salience, corporate performance, and CEO values. Academy of Management Journal, 42(5), 507-525.

Ansoff, I. H. (1979). Strategic management. London: Macmillan.

Argote, L., \& Greve, H. R. (2007). A behavioral theory of the firm-40 years and counting: Introduction and impact. Organization Science, 18(3), 337-349.

Audia, P. G., \& Greve, H. R. (2006). Less likely to fail: Low performance, firm size, and factory expansion in the shipbuilding industry. Management science, 52(1), 83-94.

Barney, J. B. (1991). Firm resources and sustained competitive advantage. Journal of Management, 17(1), 99-120.

Barreto, I., \& Baden-Fuller, C. (2006). To conform or to perform? Mimetic behaviour, legitimacy-based groups and performance consequences. Journal of Management Studies, 43(7), 1559-1581.

Baum, J. A. C., Rowley, T. J., Shipilov, A. V., \& Chuang, Y. T. (2005). Dancing with strangers: Aspiration performance and the search for underwriting syndicate partners. Administrative Science Quarterly, 50(4), 536-575.

Ben-Oz, C., \& Greve, H. R. (2012). Short-and Long-Term Performance Feedback and Absorptive Capacity. Journal of management.

Bromiley, P. (1991). Testing a causal model of corporate risk taking and performance. Academy of management Journal, 34(1), 37-59.

Cameron, K. (2010). Organizational effectiveness. Wiley Encyclopedia of Management, 11, $1-4$.

Chen, W. R., \& Miller, K. D. (2007). Situational and institutional determinants of firms' R\&D search intensity. Strategic Management Journal, 28(4), 369-381. 
Chrisman, J. J., \& Carroll, A. B. (1984). Corporate responsibility-reconciling economic and social goals. Sloan Management Review, 25(2), 59-65.

Chrisman, J. J., Chua, J. H., Pearson, A. W., \& Barnett, T. (2012). Family Involvement, Family Influence, and Family Centered Non Economic Goals in Small Firms. Entrepreneurship Theory and Practice, 36(2), 267-293.

Chrisman, J. J., \& Patel, P. J. (2012). Variations in R\&D investments of family and nonfamily firms: Behavioral agency and myopic loss aversion perspectives. Academy of Management Journal, 55(4), 976-997.

Colbert, A. E., Kristof-Brown, A. L., Bradley, B. H., \& Barrick, M. R. (2008). CEO transformational leadership: The role of goal importance congruence in top management teams. Academy of management journal, 51(1), 81-96.

Collins, J. (2017). Turning goals into results: The power of catalytic mechanisms. Boston, MA: Harvard Business Review Press.

Connolly, T., Conlon, E. J., \& Deutsch, S. J. (1980). Organizational effectiveness: A multiple-constituency approach. Academy of Management Review, 5(2), 211-218.

Cyert, R. M., \& March, J. G. (1963). A behavioral theory of the firm. Englewood Cliffs, NJ: Prentice-Hall.

Davis, G. F., \& Greve, H. R. (1997). Corporate elite networks and governance changes in the 1980s. American journal of sociology, 103(1), 1-37.

De Massis, A., Kotlar, J., Mazzola, P., Minola, T., \& Sciascia, S. (2016). Conflicting selves: Family owners' multiple goals and self-control agency problems in private firms. Entrepreneurship Theory \& Practice, In press. DOI: 10.1111/etap.12257.

Decker, C., \& Mellewigt, T. (2007). Thirty years after Michael E. Porter: what do we know about business exit?. Academy of Management Perspectives, 21(2), 41-55.

Dess, G. G. (1987). Consensus on strategy formulation and organizational performance: Competitors in a fragmented industry. Strategic management journal, 8(3), 259-277.

DiMaggio, P., \& Powell, W. W. (1983). The iron cage revisited: Collective rationality and institutional isomorphism in organizational fields. American Sociological Review, 48(2), 147-160.

Donaldson, T., \& Preston, L. E. (1995). The stakeholder theory of the corporation: Concepts, evidence, and implications. Academy of management review, 20(1), 65-91.

Dopfer, K., Foster, J., \& Potts, J. (2004). Micro-meso-macro. Journal of Evolutionary Economics, 14(3), 263-279.

Dutton, J. E., \& Dukerich, J. M. (1991). Keeping an eye on the mirror: Image and identity in organizational adaptation. Academy of management journal, 34(3), 517-554.

Ethiraj, S. K., and Levinthal, D. (2009). Hoping for A to Z while rewarding only A: Complex organizations and multiple goals. Organization Science, 20, 4-21.

Fama, E. F. (1980). Agency Problems and the Theory of the Firm. Journal of political economy, 88(2), 288-307.

Fama, E. F., \& Jensen, M. C. (1983a). Agency problems and residual claims. Journal of law and Economics, 26, 327-349.

Fama, E. F., \& Jensen, M. C. (1983b). Separation of ownership and control. Journal of law and Economics, 26, 301-325.

Fiegenbaum, A., Hart, S., \& Schendel, D. (1996). Strategic reference point theory. Strategic Management Journal, 17(3), 219-235.

Foss, N. J., Linder, S. (2017). Microfoundations of organizational goals: A review and new directions for future research. International Journal of Management Reviews, THIS ISSUE.

Freeman, R. E. (1984). Strategic management: A stakeholder approach (Vol. 1): Pitman. 
Gaba, V., and Joseph, J. (2013). Corporate structure and performance feedback: Aspirations and adaptation in M-form firms. Organization Science, 24, 1102-1119.

Gagné, M. (2017). From strategy to action: Transforming organizational goals into organizational behavior. International Journal of Management Reviews, THIS ISSUE.

Gary, M. S., Yang, M. M., Yetton, P. W., \& Sterman, J. D. (2017). Stretch Goals and the Distribution of Organizational Performance. Organization Science.

Gavetti, G., Greve, H. R., Levinthal, D. A., and Ocasio, W. (2012). The behavioral theory of the firm: Assessment and prospects. Academy of Management Annals, 6, 1-40.

Glick, W. H., Miller, C. C., \& Huber, G. P. (1993). The impact of upper-echelon diversity on organizational performance. Organizational change and redesign: Ideas and insights for improving performance, 176, 214.

Gollwitzer, P. M. (1996). Benefits of Planning. The psychology of action: Linking cognition and motivation to behavior, 287.

Gómez-Mejía, L. R., Haynes, K. T., Núñez-Nickel, M., Jacobson, K. J. L., \& MoyanoFuentes, J. (2007). Socioemotional wealth and business risks in family-controlled firms: Evidence from Spanish olive oil mills. Administrative Science Quarterly, 52(1), 106-137.

Gooding, R. Z., Goel, S., \& Wiseman, R. M. (1996). Fixed versus variable reference points in the risk-return relationship. Journal of Economic Behavior \& Organization, 29(2), 331350.

Greve, H. R. (2003). Organizational learning from performance feedback. Cambridge, UK: Cambridge University Press.

Greve, H. R. (2008). A behavioral theory of firm growth: Sequential attention to size and performance goals. Academy of Management Journal, 51(3), 476-494.

Greve, H. R.,\& Teh, D. (2017). Goal selection internally and externally: A behavioral theory of institutionalization. International Journal of Management Reviews, THIS ISSUE.

Hamel, G., Doz, Y. L., \& Prahalad, C. K. (1989). Collaborate with your competitors and win. Harvard business review, 67(1), 133-139.

Harris, J. D., Johnson, S. G., \& Souder, D. (2013). Model-theoretic knowledge accumulation: The case of agency theory and incentive alignment. Academy of Management Review, $38(3), 442-454$.

Hay, R., \& Gray, E. (1974). Social responsibilities of business managers. Academy of management journal, 17(1), 135-143.

Hinsz, V. B., Tindale, R. S., \& Vollrath, D. A. (1997). The emerging conception of groups as information processors. Psychological Bulletin, 121(1), 43-64.

Hirst, M. K. (1987). The effects of setting budget goals and task uncertainty on performance: A theoretical analysis. Accounting Review, 774-784.

Hollenbeck, J. R., Williams, C. R., \& Klein, H. J. (1989). An empirical examination of the antecedents of commitment to difficult goals. Journal of applied psychology, 74(1), 1823.

Iyer, D. N., \& Miller, K. D. (2008). Performance feedback, slack, and the timing of acquisitions. Academy of Management Journal, 51(4), 808-822.

Kahneman, D., \& Tversky, A. (1979). Prospect theory: An analysis of decision under risk. Econometrica: Journal of the Econometric Society, 47(2), 263-291.

Kaplan, R. S., \& Norton, D. P. (2007). Using the balanced scorecard as a strategic management system. Harvard business review, 85(7-8), 150-161.

Keim, G. D. (1978). Managerial behavior and the social responsibility debate: Goals versus constraints. Academy of Management Journal, 21(1), 57-68.

Kerr, S., \& Landauer, S. (2004). Using stretch goals to promote organizational effectiveness and personal growth: General Electric and Goldman Sachs. The Academy of Management Executive, 18(4), 134-138. 
Kotlar, J., \& De Massis, A. (2013). Goal setting in family firms: Goal diversity, social interactions, and collective commitment to family-centered goals. Entrepreneurship Theory and Practice, 37(6), 1263-1288.

Kotlar, J., Signori, A., De Massis, A., \& Vismara, S. (2017). Financial wealth, socioemotional wealth and IPO underpricing in family firms: a two-stage gamble model. Academy of Management Journal, in press. DOI: 10.5465/amj.2016.0256.

Labianca, G., Fairbank, J. F., Andrevski, G., and Parzen, M. (2009). Striving toward the future: aspiration-performance discrepancies and planned organizational change. Strategic Organization, 7, 433-466.

Lant, T. K. (1992). Aspiration level adaptation: An empirical exploration. Management science, 38(5), 623-644.

Latham, G. P., \& Yukl, G. A. (1975). A review of research on the application of goal setting in organizations. Academy of management Journal, 824-845.

Levinson, H. (2003). Management by whose objectives? Harvard Business Review, 81(1), 107-116.

Levitt, B., \& March, J. G. (1988). Organizational learning. Annual review of sociology, 319340.

Locke, E. A., \& Latham, G. P. (1990). A theory of goal setting \& task performance: PrenticeHall, Inc.

Locke, E. A., \& Latham, G. P. (2002). Building a practically useful theory of goal setting and task motivation: A 35-year odyssey. American psychologist, 57(9), 705-717.

Loewenstein, G., \& Thaler, R. H. (1989). Anomalies: intertemporal choice. The journal of economic perspectives, 3(4), 181-193.

March, J. G., \& Shapira, Z. (1992). Variable risk preferences and the focus of attention. Psychological Review, 99(1), 172.

March, J. G., \& Simon, H. A. (1958). Organizations. New York: John Wiley.

Martin, G. P., Gomez-Mejia, L. R., \& Wiseman, R. M. (2013). Executive stock options as mixed gambles: Revisiting the behavioral agency model. Academy of Management Journal, 56(2), 451-472.

Mayer, C., Wright, M. \& Phan, P. (2017). Management Research and the Future of the Corporation: A New Agenda. Academy of Managent Perspectives, 31(3), 179-182.

Mezias, S. J., Chen, Y.-R., \& Murphy, P. R. (2002). Aspiration-level adaptation in an American financial services organization: A field study. Management science, 48(10), 1285-1300.

Miller, C. C., Burke, L. M., \& Glick, W. H. (1998). Cognitive diversity among upper echelon executives: Implications for strategic decision processes. Strategic Management Journal, 19(1), 39-58.

Mishina, Y., Dykes, B. J., Block, E. S., \& Pollock, T. G. (2010). Why "good” firms do bad things: The effects of high aspirations, high expectations, and prominence on the incidence of corporate illegality. Academy of Management Journal, 53(4), 701-722.

Mitchell, R. K., Weaver, G. R., Agle, B. R., Bailey, A. D., \& Carlson, J. (2016). Stakeholder agency and social welfare: Pluralism and decision making in the multi-objective corporation. Academy of Management Review, 41(2), 252-275.

Mitchell, T. R., \& Silver, W. S. (1990). Individual and group goals when workers are interdependent: Effects on task strategies and performance. Journal of applied psychology, 75(2), 185.

Mohr, L. B. (1973). The concept of organizational goal. American Political Science Review, 67(2), 470-481.

Ocasio, W. (1997). Towards an attention-based view of the firm. Strategic Management Journal, 18, 187-206. 
O'Leary-Kelly, A. M., Martocchio, J. J., \& Frink, D. D. (1994). A review of the influence of group goals on group performance. Academy of management Journal, 1285-1301.

Patel, P., \& Cooper, D. (2014). Structural power equality between family and non-family TMT members and the performance of family firms. Academy of Management Journal, 57(6), 1624-1649.

Pearce, J. A., \& DeNisi, A. S. (1983). Attribution Theory and Strategic Decision Making: An Application to Coalition Formation. Academy of management Journal, 26(1), 119-128.

Pfeffer, J., \& Salancik, G. (1978). The external control of organizations: a resource dependence perspective: New York, NY: Harper \& Row.

Phan, P., Siegel, D. and Wright, M. (2016). Alternative Forms of Economic Organization: Be Careful What You Wish For. Academy of Management Perspectives, 30(2), 117-122.

Pitcher, P., \& Smith, A. D. (2001). Top management team heterogeneity: Personality, power, and proxies. Organization Science, 12(1), 1-18.

Podsakoff, P. M., MacKenzie, S. B., Paine, J. B., \& Bachrach, D. G. (2000). Organizational citizenship behaviors: A critical review of the theoretical and empirical literature and suggestions for future research. Journal of management, 26(3), 513-563.

Porter, M. E. (1980). Competitive strategy. New York: Free Press.

Porter, M. E., \& Kramer, M. R. (2014). A response to Andrew Crane et al.'s article. California Management Review, 56(2), 149-151.

Rappaport, A. (1986). Creating shareholder value: the new standard for business performance. New York: Free press.

Richard, P. J., Devinney, T. M., Yip, G. S., \& Johnson, G. (2009). Measuring organizational performance: Towards methodological best practice. Journal of Management, 35(3), 718-804.

Shalley, C. E. (1991). Effects of productivity goals, creativity goals, and personal discretion on individual creativity. Journal of Applied psychology, 76(2), 179.

Shinkle, G. A. (2012). Organizational Aspirations, Reference Points, and Goals. Journal of management, 38(1), 415-455.

Short, J. C., \& Palmer, T. B. (2003). Organizational performance referents: An empirical examination of their content and influences. Organizational Behavior and Human Decision Processes, 90(2), 209-224.

Sitkin, S. B., See, K. E., Miller, C. C., Lawless, M. W., \& Carton, A. M. (2011). The Paradox of Stretch Goals: Organizations in Pursuit of the Seemingly Impossible. The Academy of Management Review (AMR), 36(3), 544-566.

Venkatraman, N., \& Ramanujam, V. (1986). Measurement of business performance in strategy research: A comparison of approaches. Academy of management review, 11(4), 801-814.

William, R. Jr., Pieper, T., Kellermanns, F., \& Astrachan, J. (2017). Family firm goals and their effects on strategy, family, and organizational behavior: A review and research agenda. International Journal of Management Reviews, THIS ISSUE.

Zahra, S. \& Wright, M. (2011). Entrepreneurship's next act. Academy of Management Perspectives, 25(4), 67-83. 
Table 1. Summary of the Special Issue Articles

\begin{tabular}{|c|c|c|c|c|}
\hline Title & Authors & Topic & Theory & Key arguments \\
\hline $\begin{array}{l}\text { Goal selection } \\
\text { internally and } \\
\text { externally: A } \\
\text { behavioral theory of } \\
\text { institutionalization }\end{array}$ & $\begin{array}{l}\text { Greve \& } \\
\text { Teh }\end{array}$ & $\begin{array}{l}\text { The role of } \\
\text { institutional } \\
\text { environment in } \\
\text { providing } \\
\text { organizational } \\
\text { goals }\end{array}$ & $\begin{array}{l}\text { Behavioral } \\
\text { theory of } \\
\text { the firm } \\
\text { Institutiona } \\
1 \text { theory }\end{array}$ & $\begin{array}{l}\text { Organizational goals have both internal and external sources } \\
\text { Review of internal and external sources of organizational goals and their selection } \\
\text { Mechanisms through which goals enter the organization internally: } \\
\text { - Supportive Dominant Coalition } \\
\text { - Side Payments to Important Stakeholders } \\
\text { - Goal Institutionalization } \\
\text { Review of complementary gaps in the behavioral theory of the firm and institutional theory }\end{array}$ \\
\hline $\begin{array}{l}\text { Microfoundations } \\
\text { of organizational } \\
\text { goals: A review and } \\
\text { new directions for } \\
\text { future research }\end{array}$ & $\begin{array}{l}\text { Foss \& } \\
\text { Linder }\end{array}$ & $\begin{array}{l}\text { Microfoundatio } \\
\text { ns of } \\
\text { organizational } \\
\text { goals } \\
\text { Cross-level } \\
\text { aspects of } \\
\text { organizational } \\
\text { goals }\end{array}$ & $\begin{array}{l}\text { Multi- } \\
\text { theoretical } \\
\text { approach }\end{array}$ & $\begin{array}{l}\text { Organizational goals are both independent and dependent variable } \\
\text { Review of main antecedents and consequences of organizational goals in extant research } \\
\text { Review of cross-level (macro-to-micro and micro-to-macro) processes linking organizational goals to its } \\
\text { antecedents and consequences. } \\
\text { Review of main theories related to research questions: } \\
\text { - Micro: social cognitive theory; theory of mind; elaboration likelihood model; social projection theory; } \\
\text { mediating hierarchs; goal-framing theory } \\
\text { - Macro: prospect theory; cognitive biases; individual-level goal setting theory; agency theory; self- } \\
\text { determination theory }\end{array}$ \\
\hline $\begin{array}{l}\text { Family firm goals } \\
\text { and their effects on } \\
\text { strategy, family, } \\
\text { and organizational } \\
\text { behavior: A review } \\
\text { and research agenda }\end{array}$ & $\begin{array}{l}\text { William, } \\
\text { Pieper, } \\
\text { Kellerma } \\
\text { nns, \& } \\
\text { Astracha } \\
\text { n }\end{array}$ & $\begin{array}{l}\text { The antecedents, } \\
\text { characteristics } \\
\text { and outcomes of } \\
\text { organizational } \\
\text { goals in family } \\
\text { firms. }\end{array}$ & $\begin{array}{l}\text { Multi- } \\
\text { theoretical } \\
\text { approach }\end{array}$ & $\begin{array}{l}\text { Family ownership and management create family-centered goals that cause differences in behavior and } \\
\text { performance between family and non-family firms. } \\
\text { Identifies antecedents, characteristics and outcomes of family business goals, as well as moderating factors in the } \\
\text { relationship between goal antecedents, goal characteristics, and goal outcomes and the role of feedback loops. } \\
\text { - Antecedents of family firm goals include family presence, role of individual family members, founder } \\
\text { influence and leadership, family history and culture, socioemotional wealth, organizational identity, } \\
\text { succession intentions, and national culture and ethnicity. } \\
\text { - Characteristics of family firm goals include the number and heterogeneity of goals. } \\
\text { - Outcomes of family firm goals include family member relationships, socioemotional wealth, governance, } \\
\text { - management, and strategy. } \\
\text { - } \text { Foderators include founder centrality, succession, and family involvement in management. } \\
\text { balanced scorecard. }\end{array}$ \\
\hline $\begin{array}{l}\text { From strategy to } \\
\text { action: } \\
\text { Transforming } \\
\text { organizational goals } \\
\text { into organizational } \\
\text { behavior }\end{array}$ & Gagné & $\begin{array}{l}\text { How } \\
\text { organizational } \\
\text { goals are } \\
\text { transformed into } \\
\text { organizational } \\
\text { behavior }\end{array}$ & $\begin{array}{l}\text { Human } \\
\text { motivation } \\
\text { theories }\end{array}$ & $\begin{array}{l}\text { Advances Motivational Model of Organizational Goal Pursuit where a social context (organizational goals) } \\
\text { influences individual conditions (motivation), which in turn influence individual action, which influences } \\
\text { social outcomes (organizational success). } \\
\text { Provides a conceptual map of the organizational goals construct across literatures. } \\
\text { Examines the links between organizational-level goal setting, the internalization of organizational goals by } \\
\text { satisfying individual psychological needs, employees' implementation intentions, incentives and individual } \\
\text { employees' outcomes. } \\
\text { Proposes a process for transforming strategy into action based on exercises and practices. }\end{array}$ \\
\hline
\end{tabular}


Figure 1. Organizational Goals: Variety, Antecedents, Outcomes and Context

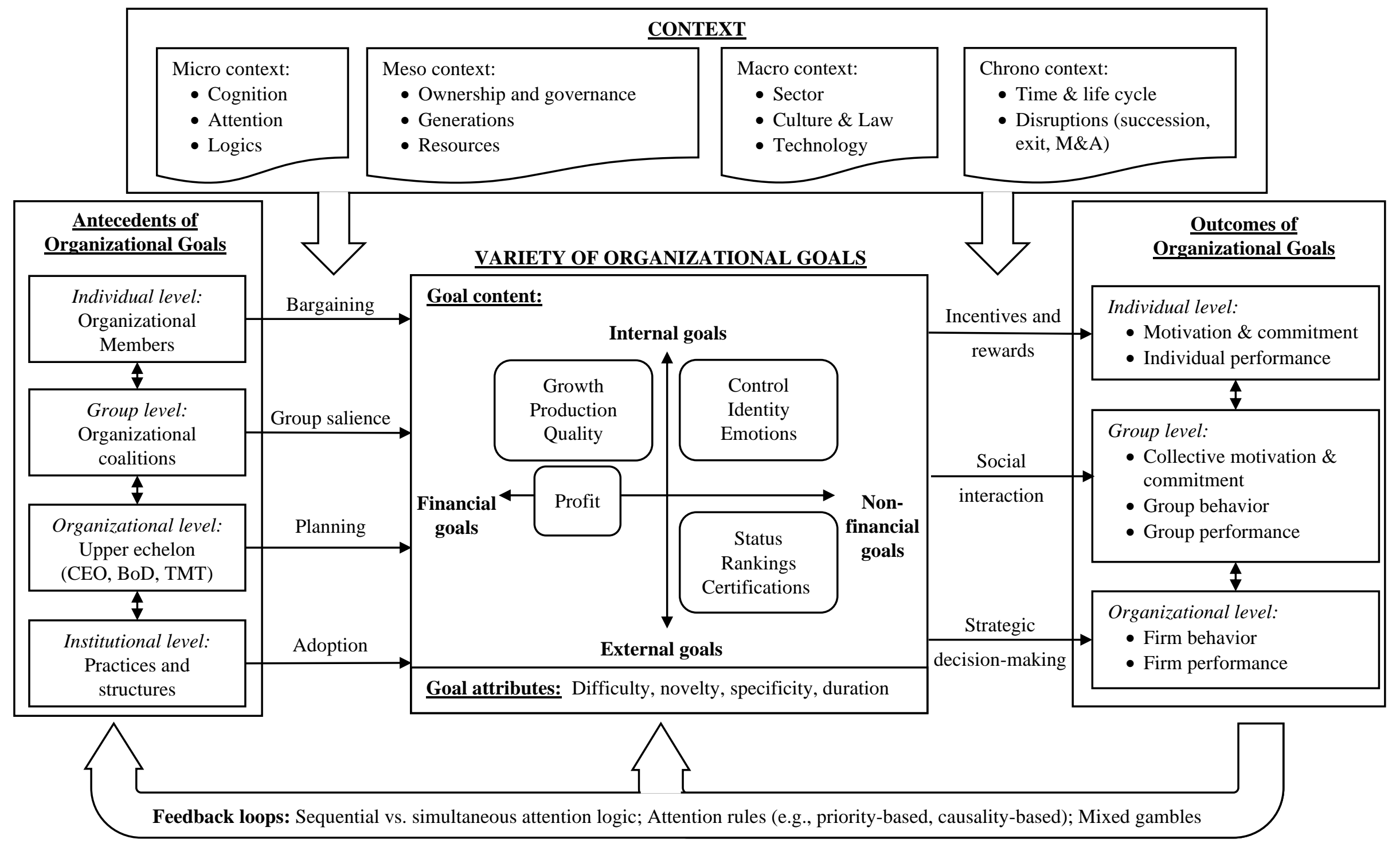


Table 2. Some Future Research Questions on Organizational Goals

\begin{tabular}{|c|c|c|c|c|}
\hline & Individual level & Group level & Organizational level & Institutional level \\
\hline 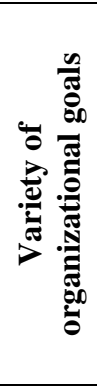 & $\begin{array}{l}\text { How are heterogeneous goals } \\
\text { prioritized/reconciled by } \\
\text { individuals and organizations? } \\
\text { Who takes the initiative in } \\
\text { resolving conflicting goals } \\
\text { between different organizational } \\
\text { members? } \\
\text { How do number and variety of } \\
\text { organizational members affect } \\
\text { goal types? }\end{array}$ & $\begin{array}{l}\text { To what extent do different } \\
\text { organizational coalitions and groups } \\
\text { have multiple [and conflicting] goals? } \\
\text { How do these differ according to } \\
\text { different types of groups? } \\
\text { To what extent can changes in ownership } \\
\text { structure and different types of new } \\
\text { owners (next generation family; private } \\
\text { equity/VC; public markets; SWFs. etc.) } \\
\text { change organizational goals? }\end{array}$ & $\begin{array}{l}\text { How do multiple goals interact? } \\
\text { What are the mutual relationships between financial } \\
\text { and non-financial, and external and internal } \\
\text { goals? } \\
\text { What are the attributes of different types of goals? } \\
\text { How does the heterogeneity of goals vary across } \\
\text { ownership types, sectors, etc.? } \\
\text { To what extent is there isomorphism regarding } \\
\text { organizational goals? }\end{array}$ & $\begin{array}{l}\text { To what extent do different institutional } \\
\text { actors create a need for organizations } \\
\text { to address multiple [and conflicting] } \\
\text { goals? } \\
\text { Does the number and heterogeneity of } \\
\text { institutions influence the types of } \\
\text { organizational goals? If yes, how? }\end{array}$ \\
\hline 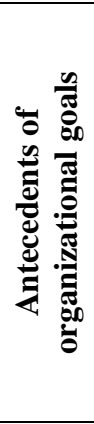 & $\begin{array}{l}\text { Are there other mechanisms, in } \\
\text { addition to bargaining and/or } \\
\text { stabilization, through which } \\
\text { organizational members can } \\
\text { influence individual goals? } \\
\text { Does the formation of individual } \\
\text { goals depends on individuals' } \\
\text { characteristics? } \\
\text { How do goals formation processes } \\
\text { differ when different types of } \\
\text { individuals are involved? }\end{array}$ & $\begin{array}{l}\text { How do organizational members, } \\
\text { organizational coalitions and } \\
\text { institutions influence each other's } \\
\text { goals, and how do they interact in } \\
\text { influencing collective and } \\
\text { organizational goals? } \\
\text { Are there other mechanisms, in addition } \\
\text { to salience, through which } \\
\text { organizational coalitions influence } \\
\text { organizational goals? }\end{array}$ & $\begin{array}{l}\text { How does the organization's upper echelon } \\
\text { influence the number and diversity of } \\
\text { organizational goals, and the processes through } \\
\text { which goals are formed? } \\
\text { How do organizations implement their goals once } \\
\text { they have been defined? } \\
\text { How does the organization identify decisions and } \\
\text { allocate tasks that must be made to pursue the } \\
\text { goals? }\end{array}$ & $\begin{array}{l}\text { How do organizational goals vary } \\
\text { between similar firms in different } \\
\text { institutional contexts? } \\
\text { To what extent do capital market actors } \\
\text { influence the nature of organizational } \\
\text { goals and their timescale? }\end{array}$ \\
\hline 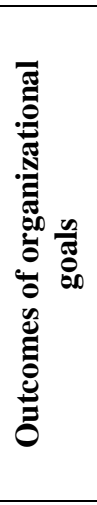 & $\begin{array}{l}\text { How do the outcomes of } \\
\text { organizational goals influence } \\
\text { individual behavior such as } \\
\text { commitment, retention, } \\
\text { turnover? } \\
\text { What incentives and rewards } \\
\text { system are better suited to } \\
\text { motivate individuals within the } \\
\text { organization? } \\
\text { Do these mechanisms vary among } \\
\text { different types of individuals and } \\
\text { depending on different types of } \\
\text { goals? }\end{array}$ & $\begin{array}{l}\text { How do the outcomes of organizational } \\
\text { goals influence group behavior such as } \\
\text { commitment, conflict, leadership, } \\
\text { turnover? } \\
\text { What social interaction mechanisms are } \\
\text { better suited to determine collective } \\
\text { motivation, behavior and performance? } \\
\text { Do these mechanisms vary depending } \\
\text { on the types of goals? }\end{array}$ & $\begin{array}{l}\text { To what extent do profits and observed performance } \\
\text { reflect the achievement of organizational goals? } \\
\text { How do financial/non-financial and } \\
\text { internal/external goals influence non-financial and } \\
\text { external/internal goals, and vice-versa? } \\
\text { How does the content of organizational goals } \\
\text { interact with goal attributes in determining } \\
\text { performance at the individual, group, and } \\
\text { organizational level? } \\
\text { What are the organizational constraints on goal } \\
\text { implementation? } \\
\text { How does planning processes change depending on } \\
\text { goal content and attributes? }\end{array}$ & $\begin{array}{l}\text { How may the pursuit of organizational } \\
\text { goals create pressures that determine } \\
\text { changes at the institutional level? } \\
\text { What's the difference between purpose } \\
\text { and goals? Have these two concepts } \\
\text { different implications at institutional } \\
\text { level? Is purpose a precursor of goals? } \\
\text { What are the implications of corporate } \\
\text { purposes for policy and decision } \\
\text { making? }\end{array}$ \\
\hline
\end{tabular}




\begin{tabular}{|c|c|c|c|c|}
\hline & $\begin{array}{l}\text { How do contextual factors such as } \\
\text { institutional policies (e.g., } \\
\text { executive remuneration, } \\
\text { pensions, and job tenure) } \\
\text { influence individual goals } \\
\text { relating to remuneration and job } \\
\text { satisfaction? } \\
\text { What are the consequences for } \\
\text { individuals' motivation, } \\
\text { commitment and performance? } \\
\text { And the consequences for } \\
\text { organizations? }\end{array}$ & $\begin{array}{l}\text { How do contextual factors such as } \\
\text { institutional policies influence group } \\
\text { goals and subsequent behavior relating } \\
\text { to remuneration and job satisfaction? } \\
\text { What are the consequences for } \\
\text { organizations and coalitions within } \\
\text { organizations? } \\
\text { Do contextual factors such as resources, } \\
\text { generation of leadership control and } \\
\text { ownership or governance } \\
\text { configurations change the processes } \\
\text { through which collective goals are } \\
\text { formed? How and why? } \\
\text { Do contextual factors such as resources, } \\
\text { generation of leadership control and } \\
\text { ownership or governance } \\
\text { configurations affect goal setting and } \\
\text { strategic planning processes? How and } \\
\text { why? }\end{array}$ & $\begin{array}{l}\text { How does context influence the relationships } \\
\text { between the antecedents and the variety of } \\
\text { organizational goals? } \\
\text { How does context influence organizational goals } \\
\text { and the relationships between organizational } \\
\text { goals and their antecedents/outcomes? } \\
\text { Do organizational goals, goal formation processes } \\
\text { and their consequences changes across firms from } \\
\text { different industries? } \\
\text { How do firms with different ownership and/or } \\
\text { governance structures differ in how they form } \\
\text { organizational goals and their } \\
\text { antecedents/consequences } \\
\text { How do technologies influence the measurement } \\
\text { and achievement of organizational goals? For } \\
\text { instance, how can social networks, big data and } \\
\text { analytics be used to collect and interpret data } \\
\text { about goal achievement and the to predict the } \\
\text { achievement of organizational goals? }\end{array}$ & $\begin{array}{l}\text { How does the social, legal and cultural } \\
\text { environment influence organizational } \\
\text { goals and the relationships between } \\
\text { organizational goals and their } \\
\text { antecedents/outcomes? } \\
\text { How do institutional and political notions } \\
\text { of the purpose of the corporation affect } \\
\text { the nature of organizational goals? } \\
\text { To what extent does the tax regime } \\
\text { influence short-term vs long-term } \\
\text { organizational goals? } \\
\text { In relation to the chrono-context, how do } \\
\text { global and national crises, stages of } \\
\text { economic development or situational } \\
\text { events such as succession and exit } \\
\text { affect organizational goals? } \\
\text { How do organizational culture and values } \\
\text { (e.g., collectivism vs. individualism) } \\
\text { and structure (e.g., power distance) } \\
\text { influence goals at different levels? }\end{array}$ \\
\hline 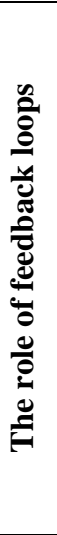 & $\begin{array}{l}\text { Under what conditions do decision } \\
\text { makers embrace different logics } \\
\text { and rules to guide attention and } \\
\text { responses to performance } \\
\text { feedback regarding multiple } \\
\text { hierarchically-related goals? } \\
\text { What response patterns do they } \\
\text { follow? Who takes the initiative } \\
\text { in the response process? } \\
\text { How do decision-makers respond } \\
\text { to incomplete, delayed and } \\
\text { ambiguous feedback on } \\
\text { organizational goals? }\end{array}$ & $\begin{array}{l}\text { What facilitates/constrains adaptation of } \\
\text { group level goals in relation to } \\
\text { organizational feedback? } \\
\text { How do group goals constrain the ability } \\
\text { of organizations to adapt to feedback/ }\end{array}$ & $\begin{array}{l}\text { How do firms use feedback to update their goals? } \\
\text { How does feedback influence the role of individual } \\
\text { organizational members, coalitions, upper } \\
\text { echelons, and institutions? } \\
\text { To what extent do organizations change or evolve } \\
\text { their goals as a consequence of feedback } \\
\text { mechanisms? When does organizational goal } \\
\text { change occur? How is goal change related to } \\
\text { organizational life-cycles? } \\
\text { How does goal change occur? What factors } \\
\text { facilitate and constrain such change? To what } \\
\text { extent? } \\
\text { What attention logics/rules work better in specific } \\
\text { circumstances? When, and why? }\end{array}$ & $\begin{array}{l}\text { How do organizations adapt goals in } \\
\text { relation to institutional change? } \\
\text { How and through which mechanisms } \\
\text { does the pursuit of organizational goals } \\
\text { determine changes in established } \\
\text { institutions? For instance, how does the } \\
\text { pursuit of social goals in businesses } \\
\text { influence the establishment of new } \\
\text { norms and regulations which, in turn, } \\
\text { affect organizational behavior? }\end{array}$ \\
\hline
\end{tabular}

